\title{
Miranda
}

Revue pluridisciplinaire du monde anglophone /

Multidisciplinary peer-reviewed journal on the English-

speaking world

$20 \mid 2020$

Staging American Nights

\section{If the Suit Fits - A Norman Mailer anecdote}

\section{Rachel Brown}

\section{OpenEdition}

\section{Journals}

Electronic version

URL: http://journals.openedition.org/miranda/26556

DOI: $10.4000 /$ miranda.26556

ISSN: 2108-6559

\section{Publisher}

Université Toulouse - Jean Jaurès

\section{Electronic reference}

Rachel Brown, "If the Suit Fits - A Norman Mailer anecdote", Miranda [Online], 20 | 2020, Online since 20 April 2020, connection on 16 February 2021. URL: http://journals.openedition.org/miranda/26556 DOI: https://doi.org/10.4000/miranda.26556

This text was automatically generated on 16 February 2021.

\section{$\Theta \Theta \Theta \Theta$}

Miranda is licensed under a Creative Commons Attribution-NonCommercial-NoDerivatives 4.0 International License. 


\title{
If the Suit Fits - A Norman Mailer anecdote
}

\author{
Rachel Brown
}

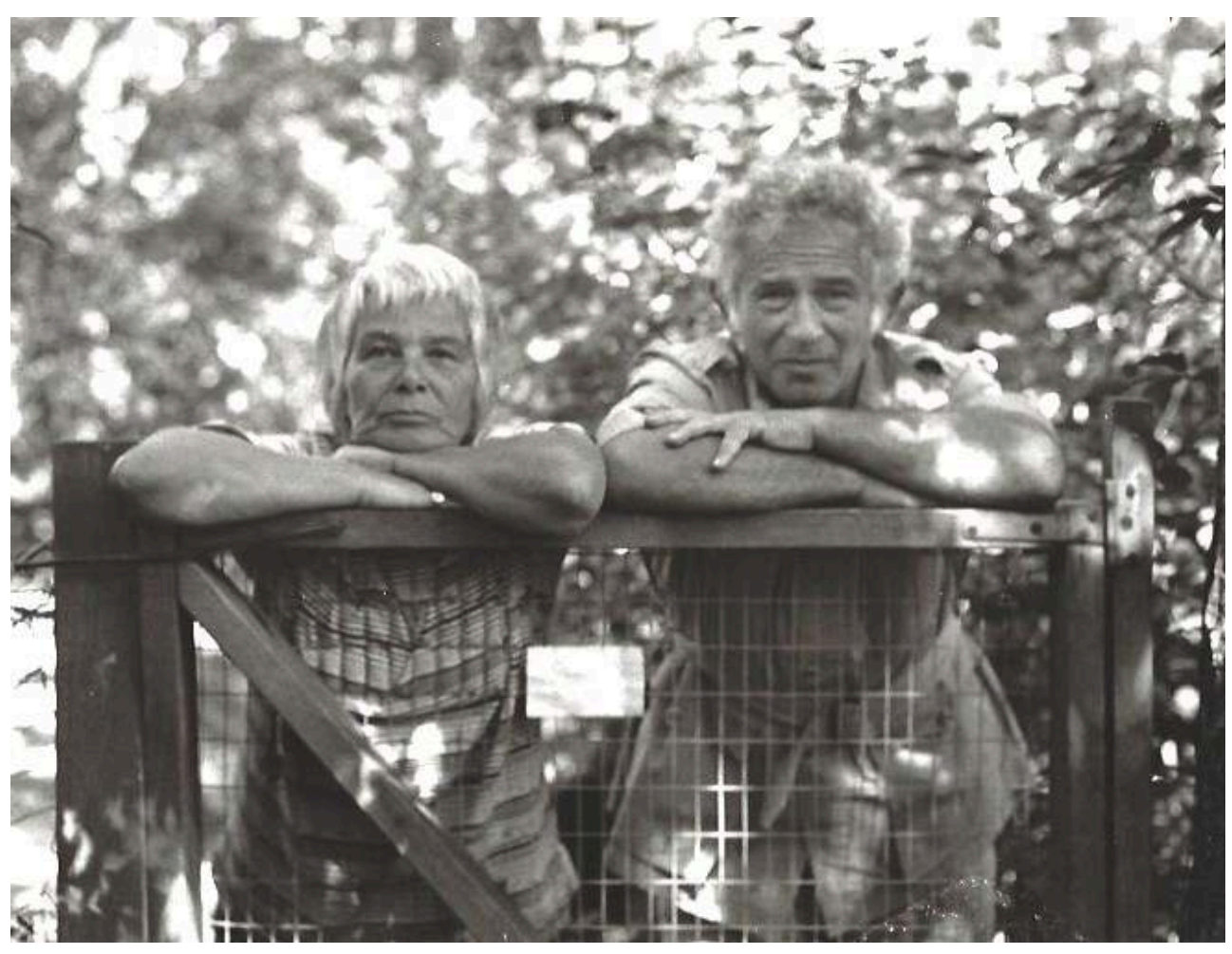

Norman Mailer and Molly Malone Cook, 1977 (photo by Rachel Giese Brown) 


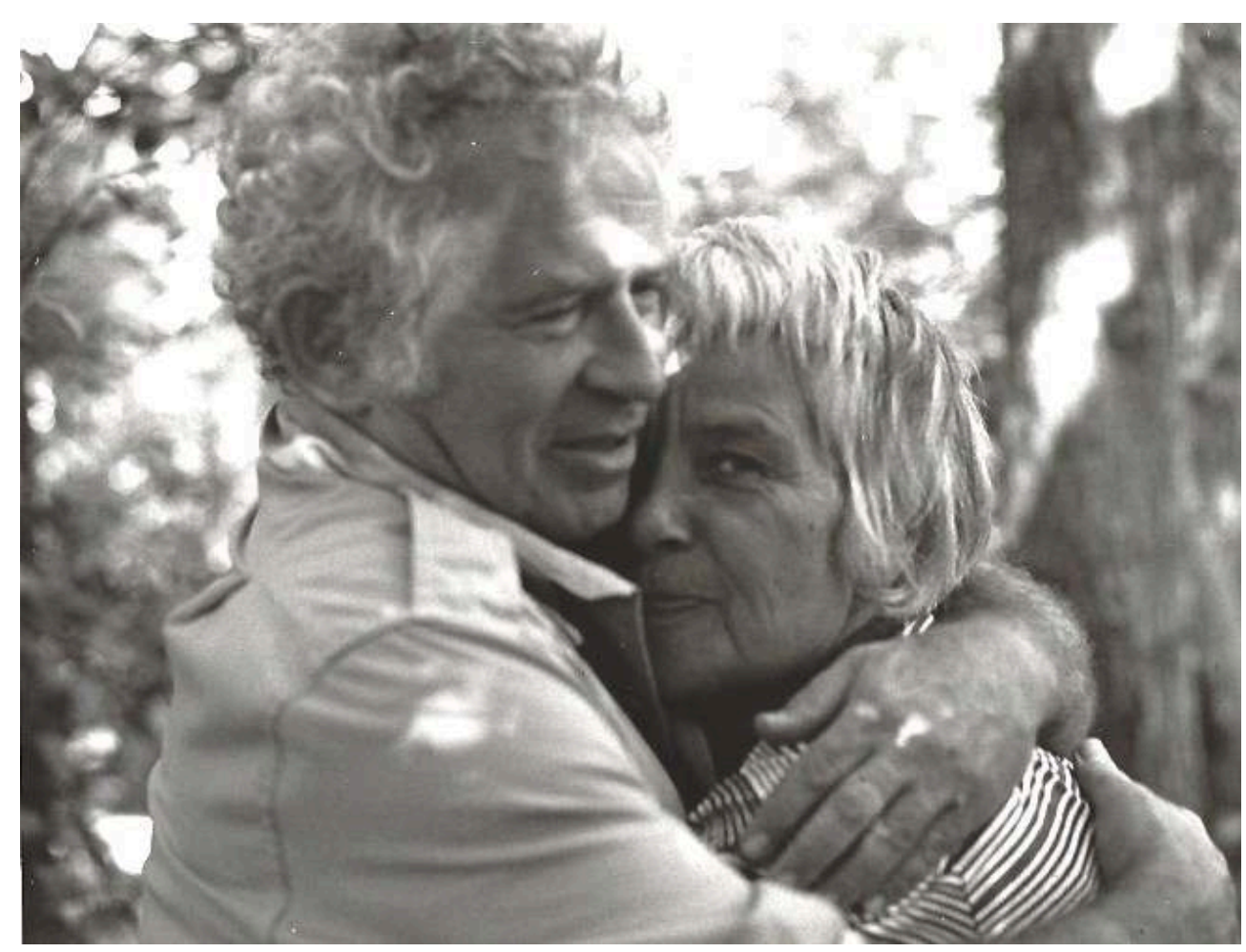

Norman Mailer and Molly Malone Cook, 1977 (photo by Rachel Giese Brown)

The two anecdotes recounted in this Miranda issue are childhood memories of photographer Rachel Brown who currently lives in Cape Cod (www.rachelbrownphoto.com).

1 Norman Mailer's new suit was hanging up in the Provincetown home of my employer, Molly Malone Cook and her partner, the poet Mary Oliver.

2 Molly and Mary were at that time both working for Norman, Mary as typist and Molly, an ex-marine, as a firewall that callers, letter writers, autograph seekers, editors, exwives and Mailer offspring had to hurdle to get to the man himself.

3 As we were friends, Molly sometimes hired me to help out from time to time to handle phone calls, do some extra typing, a dogsbody. As it happened, I was on hand when Norman got the call from Esquire Magazine.

4 It was Spring of 1977. Jimmy Carter was the new President and Norman was assigned by Esquire Magazine to go to Georgia to interview Carter.

5 Norman was highly interested in this assignment and bought a new suit well in advance for the occasion, a light beige linen sort of thing. For some reason it was kept at Molly and Mary's home instead of Norman's place at the East End.

6 So the suit was on its hanger in full sight in Molly and Mary's living-working-dining room, giving the space an air of a high priest's vestry. It couldn't have been in safer hands. After all, there were three of us looking after it.

7 As the date of Norman's trip to Georgia drew near, I noticed Molly's increasing interest in the suit.

8 One day she announced she was going to try on Norman's new suit. As Molly and Norman were roughly the same shape and size we agreed it would probably work, 
although the consequences if anything bad should happen were monumental: spilled coffee, a torn seam, dog hairs. Molly was not to be stopped. Mary and I held our breaths as Molly donned the suit.

9 She looked amazing in it. Perfect fit except a little long in the arms and legs.

10 She strode around the room, stopping in front of a mirror, then a turn outside on the deck, leaning on the rail in a pose, gazing out into the woods surrounding their house as if there were a crowd in front of her, or a president.

11 What could one say about this confluence of personalities and circumstances?

12 I stupidly said, "Oh, Molly, you look just like Norman Mailer."

13 She regarded me archly and replied, “I don't want to look like Norman Mailer. I want to be Norman Mailer.

14 And for a moment she was. ${ }^{1}$

\section{NOTES}

1. Published March 12, 2020 in Provincetown Independent

\section{INDEX}

Subjects: American art

Mots-clés: Esquire Magazine, Provincetown

Keywords: Esquire Magazine, Provincetown

\section{AUTHORS}

\section{RACHEL BROWN}

Photographer

website: www.rachelbrownphoto.com

brown.dejean@gmail.com 